\title{
가뭄저항성 $\mathrm{GM}$ 벼(Agb0103)와 non-GM 일미벼 간 표면미생물의 변화 및 병 발생 양상 비교
}

\author{
이승열 ${ }^{1} \cdot$ 백창기 ${ }^{1,2} \cdot$ 박상규 $^{1} \cdot$ 김경민 $^{1} \cdot$ 서상재 $^{1} \cdot$ 정희영 ${ }^{1^{*}}$ \\ ${ }^{1}$ 경북대학교 농업생명과학대학, ${ }^{2}$ 국립원예특작과학원
}

\section{Comparing Disease Incidence and Phyllosphere Microbial Community between Drought Resistance Transgenic Rice (Agb0103) and Non-Transgenic Rice}

\author{
Seung-Yeol Lee ${ }^{1}$, Chang-Gi Back ${ }^{1,2}$, Sangkyu Park ${ }^{1}$, SangJae Suh ${ }^{1}$, Kyung-Min Kim ${ }^{1}$, and Hee-Young Jung ${ }^{1 *}$ \\ ${ }^{1}$ College of Agriculture and Life Sciences, Kyungpook National University, Daegu 41566, Korea \\ ${ }^{2}$ National Institute of Horticultural and Herbal Science, Rural Development Administration, Wanju-gun 55365, Korea
}

\begin{abstract}
In this study, we compared disease incidence rate and phyllosphere microbial community between drought resistance transgenic rice (Agb0103) and non-transgenic Ilmi (NGM) during 2011-2014 to examine an environmental risk assessment of drought resistance transgenic rice (Agb0103). As the results, major diseases such as sheath blight, brown spot, leaf blast and false smut were occurred, however, there were no significant disease incidence rate between Agb0103 and NGM. As the results of counting bacterial and fungal viable cell, the colonies were increased or decreased which affected by environmental conditions, however there were no differences between Agb0103 and NGM. Also unweighted pair-group method with arithmetic averaging (UPGMA) analysis based on polymerase chain reaction with denaturing gel electrophoresis (PCR-DGGE) revealed that DGGE band pattern of bacterial and fungal communities were clustered by each month and there were no differences between Agb0103 and NGM. Furthermore, isolated casual agents causing sheath blight and brown spot were collected from Agb0103 and NGM, and they revealed that each of pathogens were no differences in morphology and pathogenicity. Therefore, our results suggested that Agb0103 showed no differences in disease incidence rate, characteristic of pathogens and phyllosphere community with NGM. In this way, it can be assumed that transgenic rice Agb0103 could not influence phyllosphere microorganism community and environmental conditions.
\end{abstract}

Keywords : Disease incidence, Drought resistance transgenic rice (Agb0103), PCR-DGGE, Phyllosphere microbe populations

\section{서 언}

생명공학 기술을 이용한 유전자변형작물(GMO, Genetically modified organism)은 전 세계적으로 약 1 억 헥타르가 재배 되고 있으며, 1996년 이래 최근까지 지속적으로 증가하는 추 세를 보이고 있다 (James 2014). GM 작물은 1996년 중국에 서 바이러스 저항성 담배가 처음 재배된 이래로, 주로 콩, 수 수, 옥수수, 면화 등에 제초제 저항성이나 해충저항성 형질의

\footnotetext{
*Corresponding author (E-mail: heeyoung@knu.ac.kr, Tel: +8255-950-5760, Fax: +82-05-950-6758)
}

(Received on October 20, 2015. Accepted on March 11, 2016)
작물이 주로 재배되고 있으며, 미국, 브라질, 아르헨티나, 인 도 등의 국가에서 널리 재배되고 있다(Qaim 2009, James 2014). 국내에서도 약 88종의 GM 작물에 대하여 연구를 수 행 중이며, 벼, 배추, 감자 외 9종의 $\mathrm{GM}$ 작물에 대하여 포장 실증 시험을 수행 중이다(Lee 2010). 이처럼 GM 작물의 개 발 및 연구가 활발해 짐에 따라 $\mathrm{GM}$ 작물 및 식품에 대한 안 정성 및 환경에 대한 위해성 평가에 대한 연구가 수행되고 있 고(Domingo \& Bordonaba 2011), 국내에서는 농촌진흥청에 서 주관하여 $\mathrm{GMO}$ 안전성평가 심사체계가 구축되어있다. 국 내 평가 항목 심사 사항은 일반자료, 분자생물학자료, 생리·생 태 자료, 유전·육종 자료 및 독성 및 타 생물영향자료와 같은 
6 개의 분과로 나눠져 있으며, 그 중 독성 및 타 생물영향자료 의 평가 항목으로는 숙주식물 및 도입유전자의 독성물질 생 성여부 및 미생물, 곤충 등 타생물체에 미치는 영향평가에 대 한 항목이 포함되어 있다(Kim 2004).

가뭄은 작물의 재배에 있어서 문제되고 있는 주요한 비 생물 적 요인으로서 작물의 생장 및 종자 생산에 영향을 끼치는 것으 로 알려져 있다(Huang et al. 2009). 이러한 가뭄 등의 재해로 인한 작물의 수확량 감소로 인해 저항성 작물의 개발이 절실히 요구되고 있으며, 최근 OsCDPK7, StMyb1R-1, CaMsrB2 유 전자를 이용한 가뭄저항성 형질전환 작물이 보고되어 있다 (Saijo et al. 2000, Im et al. 2012, Kim et al. 2013). 고추 (Capsicum annuum) 유래의 MSRB2(Methionine sulfoxide reductase B2) 유전자를 도입한 형질전환 벼 Agb0103은 일미 벼를 모본으로 개발된 형질변환 벼로서, 가뭄에 대해 저항성을 가지는 형질전환 벼이다(Kim et al. 2013). 최근 형질전환 $\mathrm{GM}$ 벼를 대상으로 모본인 일미벼와 곤충발생양상을 비교한 연구 가 보고되어 있으나(Kim et al. 2010, Oh et al. 2014), 병원균 에 의한 주요 병해의 발생에 대한 연구 내용은 보고된 바 없다. 이에 본 연구에서는 가뭄저항성벼 $\mathrm{GM}$ 벼 $\mathrm{Agb} 0103$ 과 모본품 종인 일미벼 간의 병해 발생 차이, 표면 미생물 군집의 변화 차 이 및 발생 병원균의 변이 발생 여부를 조사하였다. 또한 본 연 구는 가뭄저항성벼 Agb0103과 일미벼 간에서 발생하는 병해 발생양상과 병원균을 비교하여, $\mathrm{GM}$ 작물에 대한 상업화 및 안정성 검정 체계를 구축함으로써 $\mathrm{GM}$ 작물의 실용화 실현에 대한 기초자료를 제공하기 위하여 수행되었다.

\section{재료 및 방법}

\section{공시재료 및 주요 병해 발생조사}

2011년부터 2014년까지 경북대학교 농업생명과학대학 군 위 GMO 실습격리 포장에서 4년동안 non-GM 일미벼와 가 뭄저항성벼 $\mathrm{Agb} 0103$ 을 재배하고 공시재료로 이용하였다. 병 해 조사는 2011년부터 2014년까지 4년동안 벼 생육기간동안 실시되었으며, 이앙한 뒤 약 2주후인 6월 하순부터 시작하여 수확직전인 10 월 상순까지 2주 간격으로 조사하였다. 조사대 상 병해의 검정은 이전에 보고된 문헌을 참고하였으며 $(\mathrm{Ou}$ 1972, Lee and Rush 1983, Ahn et al. 2005), 병해의 조사는 농약의 등록기준 고시 (농진청고시 제2012-37호)에 따라 조 사를 실시하였다. 조사구역의 설정은 가뭄저항성벼 $\mathrm{Agb} 0103$ 과 non-GM 일미벼가 식재된 구역에 총 600 주 이상의 구역
을 3 반복으로 설정하여 각 병해의 발병률을 조사하였다. 잎도 열병과 깨씨무늬병은 잎에 나타나는 병반의 크기에 따라 병 반면적율을 측정하고, 잎집무늬마름병은 각주의 조사 경수별 병징의 진전 정도를 측정하여 피해도를 산출하였다. 키다리병 은 구당 이병주를 조사하여 이병주율로 나타내었으며, 이삭누 룩병의 경우 이병 이삭수를 조사하여 이병수율로 나타내었다. 그 외의 병해는 농약등록시험 기준에 준하여 조사하되 병 발 생의 정도에 따라 추가적인 조사 방법을 적용하였다

\section{시기별 벼 잎 표면 서식 미생물 생균수 조사}

Non-GM 일미벼와 가뭄저항성벼 Agb0103의 잎의 표면미 생물에 서식하는 생균수의 변화를 조사하기 위하여 2011년부 터 2012년까지 이앙한 30일 후부터 2주 간격으로 외관상 건 전한 잎을 채집하였다. 채집된 잎은 $0.1 \mathrm{M}$ phosphate buffer (pH 7.0) $50 \mathrm{ml}$ 에 침지시켜, $20^{\circ} \mathrm{C}$ 의 shaking incubator에서 $150 \mathrm{rpm} / \mathrm{min}$ 으로 30 분간 교반하였다. 진탕한 용액에서 상층 액 $50 \mu \mathrm{l}$ 를 항생제가 첨가되지 않은 $\mathrm{PDA}$ 배지에 도말하였고 $25^{\circ} \mathrm{C}$ 배양기에서 4 일간 배양한 후 형성되는 단일 콜로니를 계수하고, 3 회 이상 반복하여 평균값을 측정하였다.

\section{PCR- DGGE(Denaturing Gradient Gel Electrophoresis)}

\section{및 UPGMA 분석}

미생물의 total DNA 추출을 위해, 여분의 $0.1 \mathrm{M}$ phosphate buffer를 공경 $0.45 \mu \mathrm{m}$ membrane filter (Sartorius, Germany) 가 장착된 micro filtration (Kimble-Kontes, Korea)에 포집하 고, Powersoil ${ }^{\mathrm{TM}} \mathrm{DNAkit}(\mathrm{MOBIO}, \mathrm{USA})$ 를 이용하여 표면미 생물의 total DNA를 추출하였다. 품종별 벼 잎 표면의 세균 및 곰팡이의 미생물상을 분석하기 위해, 세균용 primer set인 $357 \mathrm{f}-\mathrm{GC} / 907 \mathrm{rM}$ 과 곰팡이용 primer set NL1-GC/LS2를 사 용하여 PCR을 진행하였다 (Payne et al. 2010, Cocolin et al. 2000). 357f-GC/907rM primer set로 증폭된 PCR 산물은 $6 \%$ Acrylamide/bis buffer를 이용하여 제작된 40-80\% 농 도의 gradient gel에서 $50 \mathrm{~V}$ 로 14시간 동안 전기영동을 실시 하였으며, NL1-GC/LS2 primer set로 증폭된 PCR 산물은 8 $\%$ Acrylamide/bis buffer을 이용하여 제작된 35-60\% 농도 의 gradient gel에서 $50 \mathrm{~V}$ 로 12 시간 동안 전기영동 하였다. 전기영동이 끝난 각각의 gradient gel은 Gelstar ${ }^{\mathrm{TM}}$ nucleic acid gel stain(Lonza, USA)를 사용하여 30 분간 염색한 후, UV trans illuminator로 band profiling을 실시하였다. 그 후, 

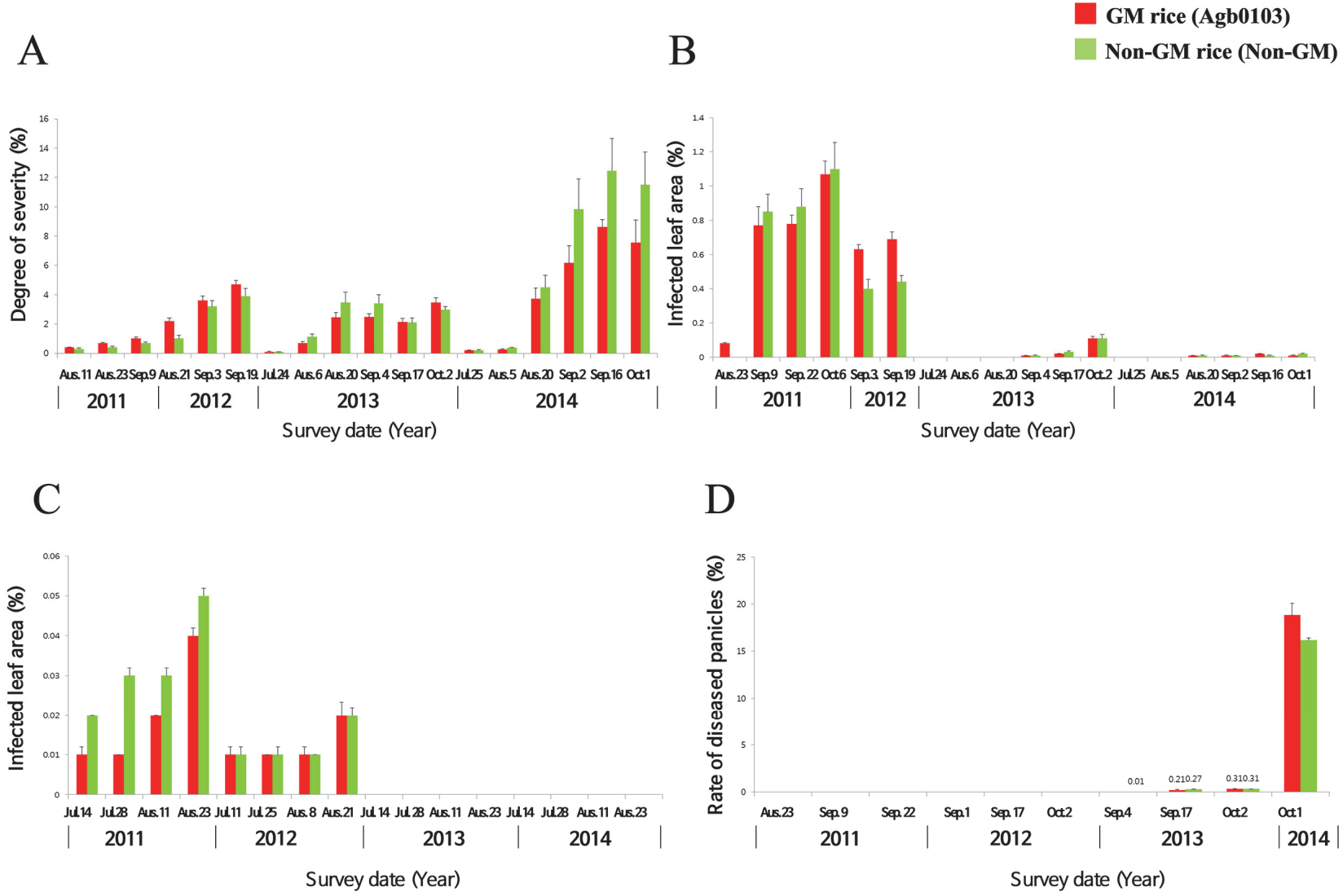

Fig. 1. Major disease incidence rate between GM and non-GM in experimental field during 2011-2014. A: Degree of severity caused by Sheath blight, B: Infected leaf area caused by Brown spot. C: Infected leaf area caused by Leaf blast, D: Rate of diseased panicles caused by False smut. Red square; GM rice (Agb0103), Green square; non-GM rice (Ilmi). Each error bar indicates the standard deviation.

NTSYSpc 2.1 프로그램을 이용하여 DGGE 사진에 나타난 band의 패턴을 측정하고 UPGMA방법을 통해 시료간의 유사 성을 분석하였다.

\section{GM벼와 Non-GM 벼 발생 병원균의 변이 검정}

2013년부터 2014년까지 조사기간 동안 가뭄저항성 $\mathrm{GM}$ 벼와 non GM 벼 품종에서 발생한 병원균의 변이여부를 조사하기 위해 시험포장에서 가장 많이 발생한 벼깨씨무늬병 및 벼잎집 무늬마름병 이병잎을 채집하고, 기내에서 병원균을 분리배양하 여 배양학적 특징 및 병원성의 차이 여부를 조사하였다. 또한 깨씨무늬병과 잎집무늬마름병은 병징에서 분리 배양 후, 병원 성 검정의 접종원으로 사용하였으며, 병원성 검정은 모본인 일 미벼를 이용하였다. 깨씨무늬병균의 경우, 농도를 측정하고 $1 \times 10^{5}$ spores $/ \mathrm{ml}$ 농도 이상의 현탁액으로 조정한 후 분무 접종하 였다. 잎집무늬마름병균의 접종은 분리균주가 완전히 배양된
$\mathrm{PDA}$ 고체배지에서 $0.5 \times 0.5 \mathrm{~cm}$ 크기의 균총 디스크를 접종 원으로 사용하였다. 이를 일미벼의 잎집부위에 붙이고 접종부 위가 마르지 않게 랩으로 감싸서 포화습도로 유지한 후, 24시간 이후 균총 디스크를 제거하였다. 깨씨무늬병균과 잎집무늬마름 병을 인공접종한 일미벼는 24시간 포화습도가 상태로 유지한 후, $25^{\circ} \mathrm{C}$ 생장상으로 옮겨 병징의 발현유무를 관찰하였다.

\section{결과 및 고찰}

\section{벼 생육시기에 따른 품종별 주요 병 발생}

2011년부터 2014년까지 4년동안 벼의 생육 기간 중 각각 의 품종에서 관찰된 주요 병해는 잎집무늬마름병, 깨씨무늬 병, 잎도열병, 이삭누룩병으로 확인되었으며, 발생된 모든 병 해에서는 가뭄저항성벼 Agb0103과 non GM 일미벼 품종간 유의한 차이는 관찰되지 않았다(Fig. 1). 또한 키다리병, 이삭 
A

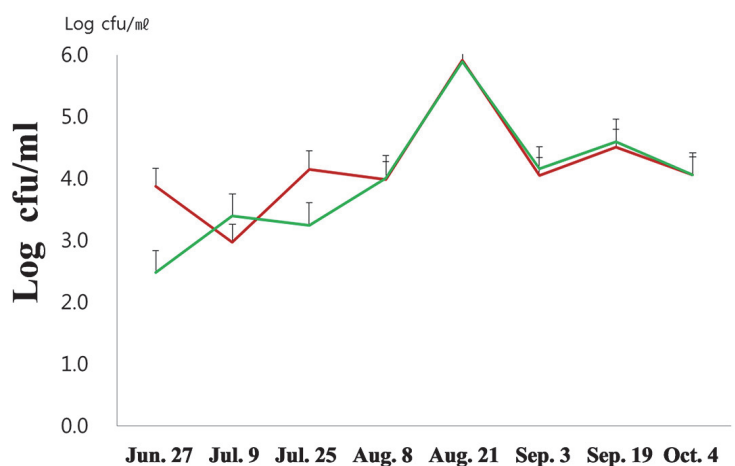

$\mathrm{C}$

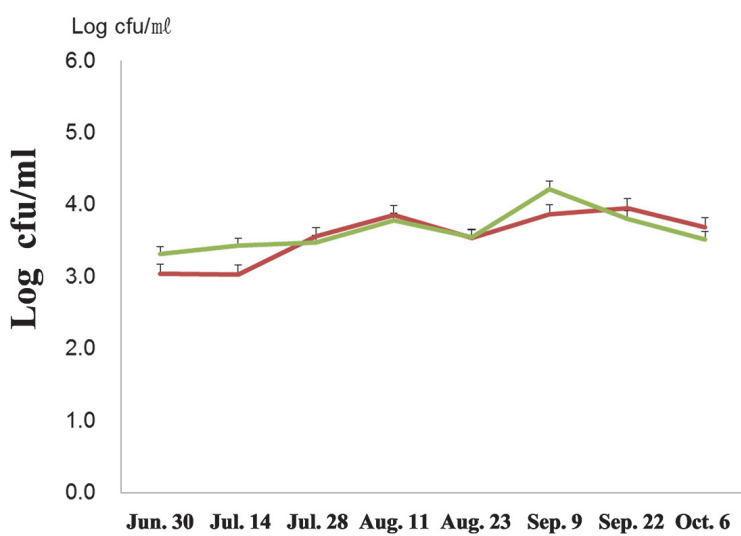

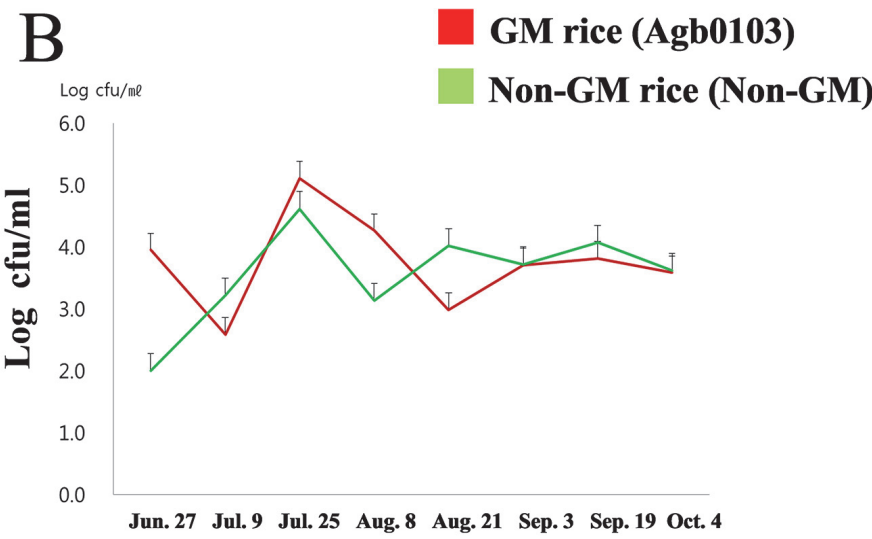

D

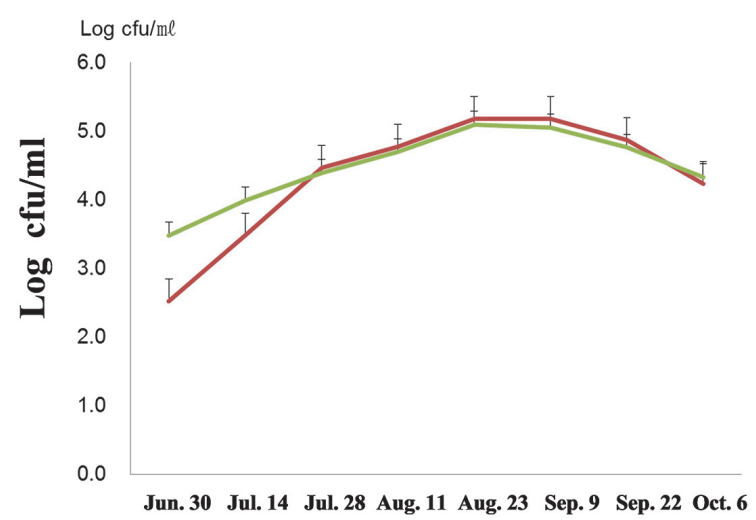

Fig. 2. Monthly variation of culturable phyllosphere living fungi and bacteria during 2011-2012. A: 2011, fungi B: 2011, bacteria C: 2012, fungi D: 2012, bacteria.

마름병 등은 발생이 미미하였으며, 흰잎마름병 및 기타 바이 러스에 의한 병해는 발생이 없었다 (Data not shown). 잎집 무늬마름병의 경우, 8 월 상순에 처음 발병하여 10 월 하순까 지 가뭄저항성벼 $\mathrm{Agb0103과} \mathrm{non} \mathrm{GM} \mathrm{일미벼} \mathrm{품종} \mathrm{모두} \mathrm{지}$ 속적으로 발생하였으나, 두 품종 간에 유의한 피해도 차이는 없었다(Fig. 1A). 깨씨무늬병은 2011년과 2012년의 경우 두 품종 모두 $0.5 \%$ 이상 발생하였고, 2013년과 2014년의 경우 깨씨무늬병의 발생이 미미하였으나 두 품종간의 차이는 관찰 할 수 없었다(Fig. 1B). 마찬가지로 잎도열병의 발병율은 2011년 7월을 제외하면 2011년과 2012년에 품종간 유의한 차이는 없었고, 2013년과 2014년에는 거의 발생하지 않았다 (Fig. 1C). 이삭누룩병은 2011년부터 2013년까지 거의 발생 하지 않았고, 2014년 평균 $15 \%$ 이상의 높은 이병수율로 발 생하였으나, 두 품종간 유의한 차이는 없었다(Fig. 1D). 1999 년부터 2008년 까지 전국적인 벼 주요 병해 발생상황을 조사
한 결과에 따르면, 잎도열병의 경우 전국적인 발생이 점차적 으로 감소하는 경향이 확인되었고, 깨씨무늬병의 경우 시비 조건에 따라 발생이 증가 또는 감소하며, 잎집무늬마름병과 이삭누룩병의 발생은 기상조건에 영향을 많이 받는다고 보고 되어있다(Lee et al. 2010). 이처럼 본 연구에서 조사되었던 벼 주요병해 발생상황도 이전 보고와 유사하였으며, 가뭄저항 성 $\mathrm{GM}$ 벼와 non-GM 일미벼에서도 유의한 차이는 없는 것으 로 확인되었다.

\section{품종별 벼 표면미생물의 군집변화}

$\mathrm{GM}$ 벼와 non-GM 일미벼 표면에서 서식하는 세균과 곰팡 이의 생균수를 조사한 결과, 두 품종간에 사이의 유의한 차이 는 관찰 할 수 없었다(Fig. 2). 하지만 생육기간에 따른 생균 수의 변화를 관찰할 수 있었다. 2011년에는 곰팡이의 경우 8 월 하순까지 지속적으로 생균수가 증가하다가 9월 상순에 감 
A

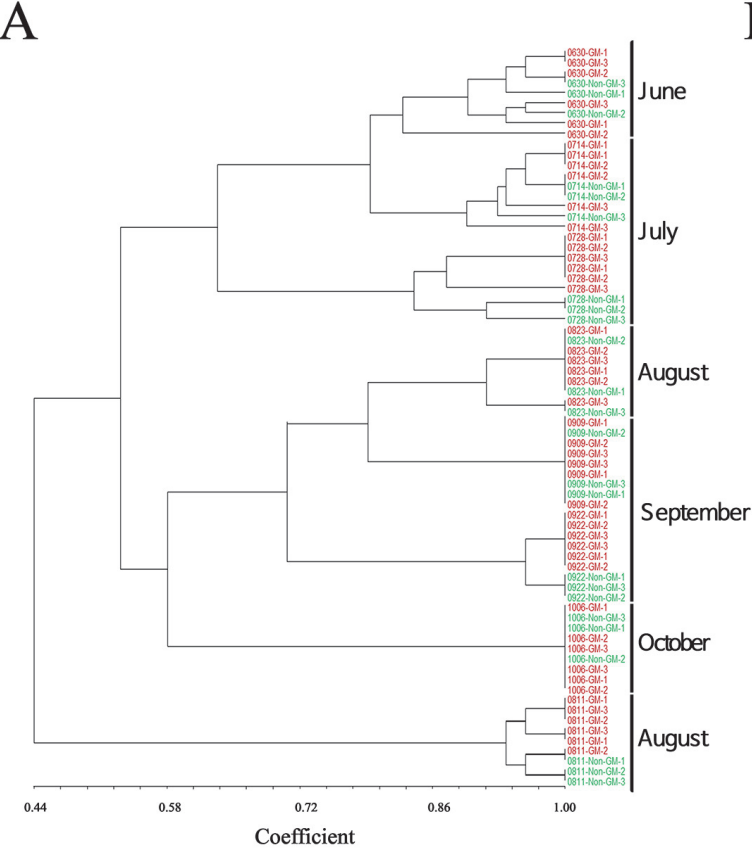

$\mathrm{C}$

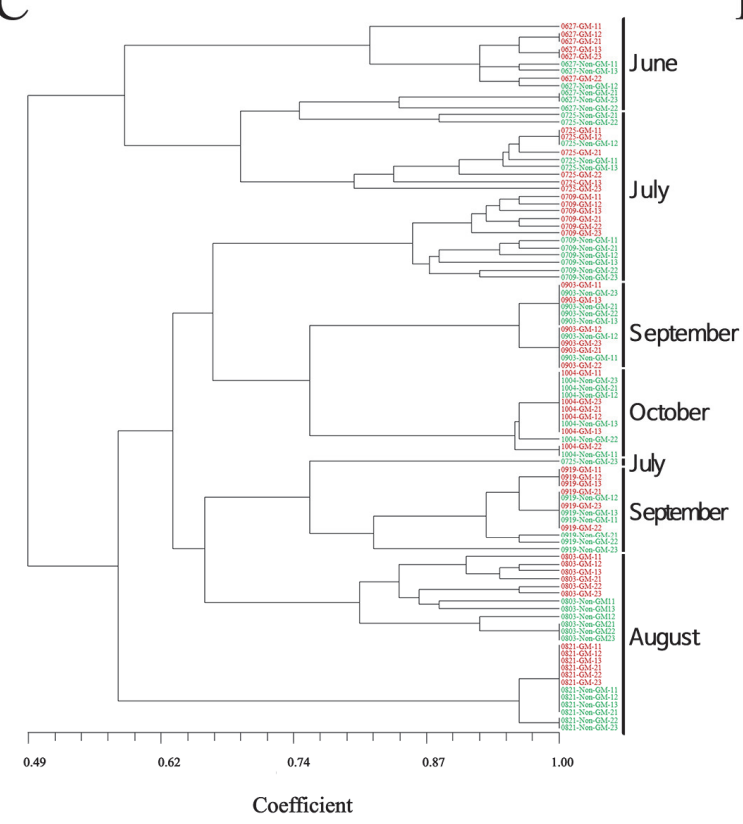

B

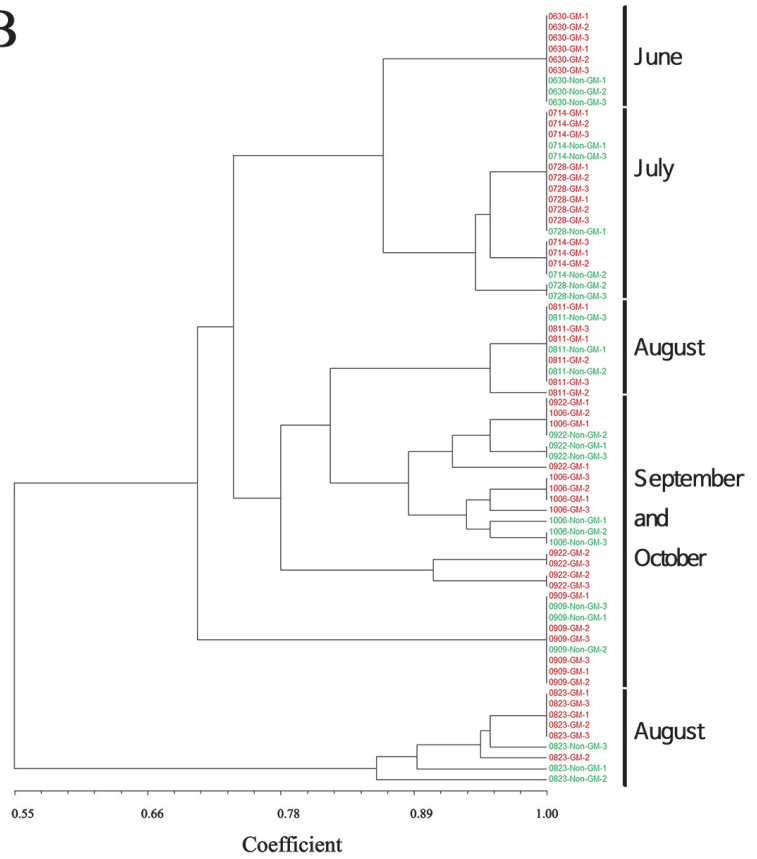

$\mathrm{D}$

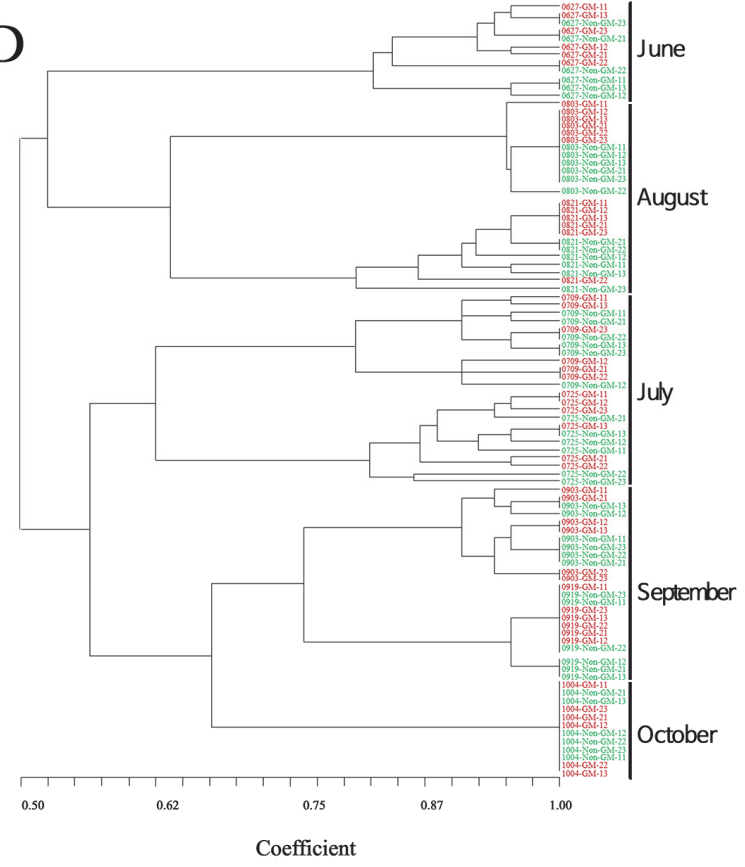

Fig. 3 UPGMA cluster analysis based on PCR-DGGE band pattern results from GM and Non-GM rice. A: Analysis results of fungi in 2012, B: Analysis result of bacteria in 2012.

소하는 양상을 보였고(Fig. 2A), 세균의 경우 7월 하순에 가 장 많은 생균수를 보인 뒤 이후 지속적으로 감소하여 수확 직 전에는 6월 말과 비슷한 수준의 생균수를 보였다(Fig 2B). 2012년의 조사 결과에서는 곰팡이의 생균수가 9월 상순까지 지속적으로 증가하는 양상을 보였지만 2011년에 비해 변화의
폭이 매우 적어졌고(Fig. 2C), 세균의 경우 2011년과 달리 9 월 상순까지 지속적으로 증가하는 결과가 나타났으며 변화의 폭도 곰팡이에 비해 크게 나타났다(Fig. 2D). 또한 월별로 추 출한 곰팡이와 세균의 total genomic DNA를 이용하여 PCR-DGGE분석을 수행하고 그 결과를 UPGMA분석을 통 


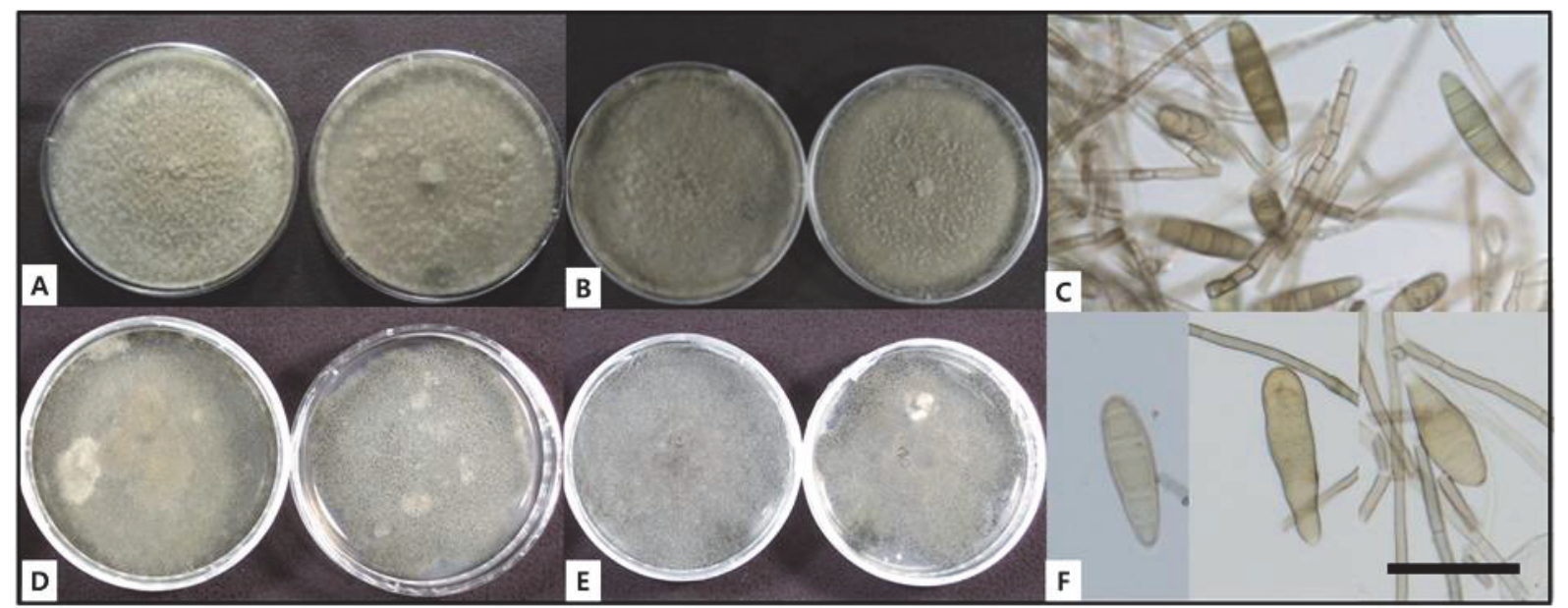

Fig. 4. Isolated Cochliobolus miyabianus from tolerance resistance GM rice and non GM Rice Ilmi on PDA during 2013-2014. A: Isolated from GM Rice in 2013, B: Isolated from non-GM Rice in 2013, D: Isolated from GM Rice in 2014, E: Isolated from non-GM Rice in 2014, C and F: Conidia of C. miyabianus. Scale bar: 50um.

해 정리한 결과, 세균과 곰팡이 모두 DGGE band의 패턴이 월별로 결집되는 것으로 확인 되었다(Fig. 3). 같은 시기에 채 집한 시료의 경우 가뭄저항성 $\mathrm{GM}$ 벼와 non-GM 일미벼가 함 께 그룹을 형성하지 않고, 혼재되어 월별로 그룹을 형성하는 것으로 나타났다(Fig. 3). 이는 앞서 생균수의 실험 결과와 마 찬가지로 $\mathrm{GM}$ 벼와 non-GM벼의 엽권미생물의 군집 구조는 거 의 차이가 없으며 미생물의 군집은 시기에 따라 변화한다는 것 으로 사료되었다. 결론적으로, 가뭄저항성 $\mathrm{GM}$ 벼와 non-GM 일미벼의 엽권미생물의 군집 구조 및 미생물 총량은 차이가 없으며, 시기별로 강수량 및 일조량에 따라 표면 미생물의 군 집이 변화한다고 할 수 있었다(Fig. 2 and 3). Fructan 합성 $\mathrm{GM}$ 감자 및 서로 다른 품종의 non-GM 감자의 근권 및 엽권세 균의 군집 변화를 T-RFLP(Terminal restriction fragment length polymorphism)법으로 분석한 결과에서도 $\mathrm{GM}$ 벼와 non-GM벼 의 근권 및 엽권세균에서는 유의한 차이가 없었다고 보고되 었으며(Saha et al. 2007), GM 콩, 배추 및 벼에서도 non-GM 작물과 근권미생물의 군집변화는 나타나지 않는다 고 보고 되어 있다(Lee et al. 2011, Sohn et al. 2010, Oh et al. 2013). 따라서 이전 결과와 마찬가지로, 본 연구에서 조 사된 가뭄 저항성 형질전환 벼 Agb0103 와 non-GM 일미벼 역시 엽권에서 미생물 군집의 차이가 없는 것을 확인하였다.

\section{GM벼와 Non-GM벼에서 발생한 병원균의 검정}

2013년부터 2014년까지 조사시기인 7월부터 10월까지 생 육기간 동안 가뭄저항성 $\mathrm{GM}$ 벼 Agb0103과 non-GM 일미벼
에서 가장 많이 발생한 잎집무늬마름병과 깨씨무늬병균을 분 리배양하여 균주를 확보하였다. 2013년부터 2014년까지 가 뭄저항성 $\mathrm{GM}$ 벼 $\mathrm{Agb0103}$ 과 non-GM벼에서 분리한 깨씨무 늬병균의 경우 배양학적으로 차이가 없었으며, 분생포자를 관 찰하였을 때도 모두 동일하게 나타났다(Fig. 4). 또한 2013년 부터 2014년까지 확보된 잎집무늬마름병균의 경우 마찬가지 로 배양학적, 형태적 차이점은 두 품종간에 전혀 관찰되지 않 았다(Fig. 5). 또한 두 품종에서 분리된 깨씨무늬병균 및 잎집 무늬마름병균을 일미벼를 대상으로 접종실험을 수행한 결과, 분리된 균주에서 모두 병원성이 확인 되었으나, 병원학적 차 이는 없는 것으로 확인되었다(Data not shown).

$\mathrm{GM}$ 작물은 1992년 중국에서 처음 재배이래로, 현재까지 미국, 아르헨티나, 캐나다 및 인도에서 주요하게 재배되고 있 으며, 미국의 경우 대규모 재배가 시작된 1996년 이래로 GM 작물의 재배 면적이 현저히 증가되고 있는 추세이다(Enriquez et al. 2001). 이처럼 GM작물의 재배 면적이 증가하면서 $\mathrm{GM}$ 작물에 대한 환경 위해성 평가가 수행되고 있다(Schrøder et al. 2007, Lim et al. 2014). 특히 GM 작물의 근권 및 엽권의 미생물의 분포를 non-GM과 비교한 연구는 제초제 저항성 $\mathrm{GM}$ 콩 및 $\mathrm{GM}$ 벼, 해충 저항성 $\mathrm{GM}$ 배추 등에서 수행이 되 었으며, $\mathrm{GM}$ 작물과 non-GM 작물 간에 근권미생물의 군집 변화는 나타나지 않는다고 보고되어 있다(Lee et al. 2011, Oh et al. 2013, Sohn et al., 2010, Sohn et al. 2012).

본 연구는 가뭄저항성 $\mathrm{GM}$ 벼 $\mathrm{Agb0103}$ 의 생육시기 중 주 변 생물체에 미치는 영향평가를 위하여 non-GM 모본품종인 


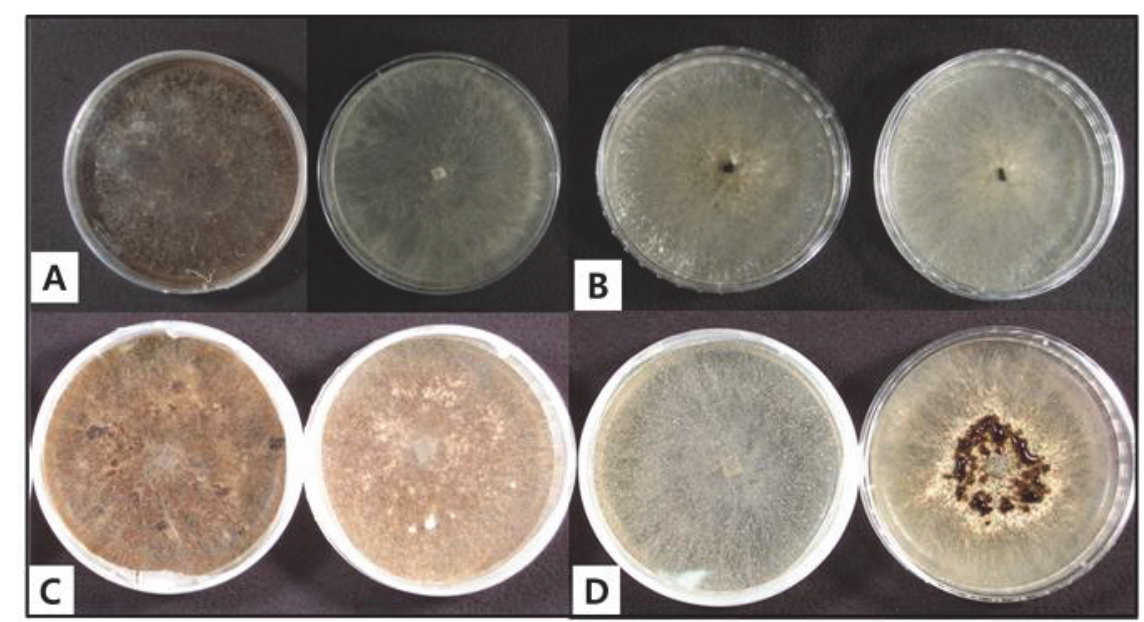

Fig. 5. Isolated Rhizoctonia solani from tolerance resistance GM rice and non GM Rice Ilmi on PDA during 2013-2014. A: Isolated from GM Rice in 2013, B: Isolated from non GM Rice in 2013, C: Isolated from non GM Rice in 2014, D: Isolated from non GM Rice in 2014.

일미벼와 비교하여 발생된 주요병해, 잎 표면 미생물 군집구 조 및 분리된 병원균의 배양학적, 병원학적 차이를 조사하였 다. 조사결과, 두 품종간에는 주요병해의 발병률, 엽권미생물 의 생균수, PCR-DGGE 분석에 따른 군집변화 및 각 품종에 서 분리된 병원균의 특징 및 접종실험 결과가 차이가 없는 것 으로 확인되었다. 또한, 가뭄저항성 $\mathrm{GM}$ 벼 $\mathrm{Agb} 0103$ 와 모본 주인 일미벼에서 발생하는 해충 및 천적곤충의 개체군 밀도 는 차이가 없는 것으로 보고되어있다(Oh et al. 2014). 따라 서 본 연구에서 조사된 가뭄저항성 $\mathrm{GM}$ 벼 $\mathrm{Agb} 0103$ 은 엽권 및 근권에서 서식하는 미생물에 영향을 주지 않으며, 생태계 에 영향을 미치는 않을 것으로 사료된다.

\section{적 요}

본 연구에서는 가뭄저항성 $\mathrm{Agb0103} \mathrm{GM}$ 벼의 환경위해성 평 가를 위해, 2011년부터 2014년까지 4년간 가뭄저항성 GM벼 (Agb0103)와 모본주인 일미벼(NGM)의 생육기간 동안 병 발생 양상 및 엽권미생물 분포를 조사하였다. 그 결과, 품종간 주요하 게 발생한 병해는 잎집무늬마름병, 깨씨무늬병, 잎도열병 및 이삭 누룩병이었고 $\mathrm{Agb0103}$ 과 $\mathrm{NGM}$ 에서는 품종간 유의한 발병율의 차이를 보이지 않았다. $\mathrm{Agb} 0103$ 과 $\mathrm{NGM}$ 의 엽권미생물의 생균수를 조사한 결과, 세균과 곰팡이의 생균수는 환경영향에 의해 각각 증가하 거나 감소하는 경향을 보였고 품종간에는 차이는 확인 할 수 없었다. 또한 polymerase chain reaction with denaturing gel electro-
phoresis(PCR-DGGE) 결과를 기반으로 한 UPGMA 분석 결과에서도 세균과 곰팡이의 DGGE 밴드 패턴은 모두 월별로 결집되었으며, $\mathrm{Agb0103}$ 과 NGM 간에 차이는 확인되지 않았다. Agb0103과 $\mathrm{NGM}$ 품종에서 주요하게 발생한 깨씨무늬병과 잎집무늬마름병을 분리하고 접종한 결과, 각 병원균은 병원학적, 형태학적 특성에서 품종별로 차이가 없었다. 따라서 가뭄저항성 형질을 갖는 $\mathrm{GM}$ 벼 $\mathrm{Agb0103}$ 은 병 발생, 발병 균의 특성 및 표면미생물의 발생 양상이 모본주인 일미벼와 유의한 차이가 없는 것으로 확인되었으며, 엽권 미생물과 환경에 영향을 끼치지 않을 것으로 사료된다.

\section{사 사}

본 연구는 농촌진흥청 차세대 바이오그린21사업(과제번호: PJ009505042014)의 지원에 의해 이루어진 것임.

\section{REFERENCES}

1. Ahn IP, Kim S, Kang S, Suh SC, Lee YH. 2005. Rice defense mechanisms against Cochliobolus miyabeanus and Magnaporthe grisea are distinct. Phytopathology 95: 1248-1255.

2. Cocolin L, Bisson LF, Mills DA. 2000. Direct profiling of the yeast dynamics in wine fermentations. FEMS Microbiol. Lett. 189: 81-87. 
3. Domingo JL, Bordonaba JG. 2011. A literature review on the safety assessment of genetically modified plants. Environ. Int. 37: 734-742.

4. Enriquez J. 2001. Green biotechnology and European competitiveness. Trends Biotechnol. 19: 135-139.

5. Huang XY, Chao DY, Gao JP, Zhu MZ, Shi M, Lin HX. 2009. A previously unknown zinc finger protein, DST, regulates drought and salt tolerance in rice via stomatal aperture control. Genes Dev. 23: 1805-1817.

6. Im JS, Cho KS, Cho JH, Park YE, Cheun CG, Kim HJ, Cho HM, Lee JN, Jin YI, Byun MO, Kim DY, Kim MJ. 2012. Growth, quality, and yield characteristics of transgenic potato (Solanumtunerosum L.) overexpressing StMyb1R-1 under water deficit. J. Plant Biotechnol. 39: 154-162.

7. James C. 2014. Global Status of Commercialized Biotech/GM Crops: 2014. No. 49. ISAAA: Ithaca, NY.

8. Kim HJ. 2004. Proceedings of the Korean Society of Plant Biotechnology Conference. 72-74.

9. Kim JS, Park HM, Chae S, Lee TH, Hwang DJ, Oh SD, Park JS, Song DG, Pan CH, Choi D, Kim YH, Nahm BH, Kim YK. 2013. A pepper MSRB2 gene confers drought tolerance in rice through the protection of chloroplast-targeted genes. Plos One 9: e90588.

10. Kim KM, Ryu TH, Suh SJ. 2010. Studies on insect diversity related to genetically engineered vitamin A rice under large scale production. Korean J. Breed. Sci. 42: 157-162.

11. Lee FN, Rush MC. 1983. Rice sheath blight: A major rice disease. Plant Dis. 67: 829-832.

12. Lee KJ, Sohn SI, Lee JY, Yi BY, Oh SD, Kweon SJ, Suh SC, Ryu TH, Kin KH, Park JS. 2011. Effects of transgenic soybean cultivation on soil microbial community in the rhizosphere, Korean J. Environ. Agric. 30: 466-472.

13. Lee SW. 2010. Current status on the development and commercialization of GM plants. J. Plant Biotechnol. 37: 305-312.

14. Lee YH, Ra DS, Yeh WH, Choi HY, Myung IS, Lee SW, Lee YH, Han SS, Shim HS. 2010. Survey of major disease incidence of rice in Korea during 1999-2008. Res. Plant Dis. 16: 183-190.

15. Lim JH, Shim MS, Oh KH, Seo JY, Lee SY, Park SK, Shin HK, Cho MR. 2014. Assessment of substantial equivalence and environmental risk for event selection of genetically modified Chrysanthemum. Kor. J. Hort. Sci. Technol. 32: 517-524.

16. Oh SD, Ahn BO, Kim MK, Sohn SI, Ryu TH, Cho HS, Kim CG, Baek KW, Lee KJ. 2013. Effects of protox herbicide tolerance rice cultivation on microbial community in paddy soil. Korean J. Environ. Agric. 32: 95-101.

17. Oh SD, Kim J, Lee K, Ryu TH, Suh SJ. 2014. Studies on insect diversity related to drought-tolerant transgenic (Agb0103) rice in large scale GMO field. Korean J. Breed. Sci. 46: 136-142.

18. Ou SH. 1972. Rice Diseases, Commonwealth Mycological Institute, Kew, Surrey, England. p. 368.

19. Payne MS, Goss KCW, Connett GJ, Kollamparambil T, Legg JP, Thwaites R, Ashton M, Puddy V, Peacock JL, Bruce KD. 2010. Molecular microbiological characterization of pre-term neonates at risk of brochopulmonary dysplasia. Pediatr. Res. 67: 412-418.

20. Qaim M. 2009. The economics of genetically modified crops. Annu. Rev. Resour. Econ. 1: 665-694.

21. Saha N, Ulrich A, Becker R, Wirth S. 2007. Assessing the changes in bacterial diversity in rhizosphere and phyllosphere of transgenic and non-transgenic potato plant. Plant Tissue Cult. Biotech. 17: 87-95.

22. Saijo YS, Hata S, Kyozuka J, Shimamoto K, Izui K. 200 0 . Over-expression of a single $\mathrm{Ca}^{2+}$-dependentpreteinkinas econfersbothcoldandsalt/droughttoleranceonriceplants.Plant J.23: 319-327.

23. Schrøder M, Poulsen M, Wilcks A, Kroghsbo S, Miller A, Frenzel T, Danier J, Rychlik M, Emami K, Gatehouse A, Shu Q, Engel KH, Altosaar I, Knudsen I. 2007. A 90-day safety study of genetically modified rice expressing CrylAb protein (Bacillus thuringiensis toxin) in Wistar rats. Food Chem. Toxicol. 45: 339-349.

24. Sohn SI, Ahn BO, Chi HY, Cho MS, Shin KS. 2012. Assessment of microbial community in paddy soils cultivated with $\mathrm{Bt}$ and nakdong rice. Korean J. Soil Sci. Fertilizer. 45: 829-835.

25. Sohn SI, Oh YJ, Oh SD, Kim MK, Ryu TH, Lee KJ, Suh SC, Baek HJ, Park JS. 2010. Molecular analysis of microbial community in soils cultivation BT Chinese cabbage. Korean J. Environ. Agric. 29: 293-299. 